ORIGINAL ARTICLE

\title{
CIPROFLOXACIN RESISTANCE PATTERN AMONG BACTERIA ISOLATED FROM PATIENTS WITH COMMUNITY-ACQUIRED URINARY TRACT INFECTION
}

\author{
Ana Carolina Costa REIS(1), Susana Regia da Silva SANTOS(1), Siane Campos de SOUZA(1,2), Milena Góes SALDANHA(2), \\ Thassila Nogueira PITANGA(3) \& Ricardo Riccio OLIVEIRA(3)
}

\begin{abstract}
SUMMARY
Objective: To identify the main bacterial species associated with community-acquired urinary tract infection (UTI) and to assess the pattern of ciprofloxacin susceptibility among bacteria isolated from urine cultures. Methods: We conducted a retrospective study in all the patients with community-acquired UTI seen in Santa Helena Laboratory, Camaçari, Bahia, Brazil during five years (20102014). All individuals who had a positive urine culture result were included in this study. Results: A total of 1,641 individuals met the inclusion criteria. Despite the fact that participants were female, we observed a higher rate of resistance to ciprofloxacin in males. The most frequent pathogens identified in urine samples were Escherichia coli, Klebsiella pneumoniae and Staphylococcus saprophyticus. Antimicrobial resistance has been observed mainly for ampicillin, sulfamethoxazole + trimethoprim and ciprofloxacin. Moreover, $E$. coli has shown the highest rate of ciprofloxacin resistance, reaching $36 \%$ of ciprofloxacin resistant strains in 2014. Conclusion: The rate of bacterial resistance to ciprofloxacin observed in the studied population is much higher than expected, prompting the need for rational use of this antibiotic, especially in infections caused by E. coli. Prevention of bacterial resistance can be performed through control measures to limit the spread of resistant microorganisms and a rational use of antimicrobial policy.
\end{abstract}

KEYWORDS: Ciprofloxacin; Antimicrobial resistance; Escherichia coli; Urinary tract infection.

\section{INTRODUCTION}

Urinary tract infection (UTI) is a common cause of morbidity in the population, representing a good proportion of medical appointments among public health services, second only to respiratory infections ${ }^{1,2}$. The main bacterial pathogens isolated from UTI patients include gramnegative Enterobacteriaceae, such as Escherichia coli, Klebsiella pneumoniae and Proteus mirabilis, and gram-positive species, such as Staphylococcus spp. and Streptococcus spp. ${ }^{1,3}$. The treatment and control of UTIs are accomplished through drug therapy with antibiotics of different classes.

Antibiotics are natural or synthetic compounds that are able to inhibit microbial growth or directly kill bacteria or fungi. Some classes of antibiotics can be used in the treatment of UTI, especially those with greater activity against gram-negative bacteria, the main etiological agents of community-acquired UTI, such as $\beta$-lactams, fluoroquinolones, aminoglycosides and sulfamethoxazole+trimethoprim ${ }^{4}$. The increase in $\beta$-lactam and sulfamethoxazole+trimethoprim antimicrobial resistance over the past years led to the use of fluoroquinolones as the first choice for empiric treatment of UTI. Fluoroquinolones, antibiotic class to which ciprofloxacin belongs, are synthetic antibiotics acting on enzymes that are essential for bacterial viability ${ }^{5,6}$.

Ciprofloxacin is indicated for complicated and uncomplicated infections caused by susceptible microorganisms. This antibiotic has a broad spectrum of activity and is used to treat bacterial infections in several anatomical sites, such as respiratory tract infections, otitis media, sinusitis, eye infections, UTI and sepsis ${ }^{7,8}$. When fluoroquinolones have emerged there was a significant and transitory reduction of infections caused by resistant bacteria. However, shortly after, concerns about bacterial resistance also came to fluoroquinolones ${ }^{5,9}$. A study conducted in Brazil in 2012 showed $10 \%$ of E. coli and 19\% of K. pneumoniae resistant to ciprofloxacin isolated from urine samples ${ }^{10}$. A more recent study, also carried out in Brazil, has shown $35 \%$ of E. coli resistant to ciprofloxacin, drawing attention to the significant increase in the rate of resistance to this drug ${ }^{11}$.

Bacterial resistance can occur by different mechanisms: alterations of the cell permeability, changes in the site of action leading to loss of susceptibility to the antibiotic mediated by the increment of the efflux pump activity and by enzymatic degradation of the antibiotic ${ }^{12-14}$.

(1) Escola Bahiana de Medicina e Saúde Pública. Salvador, BA, Brazil.

(2) Laboratório Santa Helena. Camaçari, BA, Brazil.

(3) Centro de Pesquisas Gonçalo Moniz (CPqGM) - FIOCRUZ-BA. Salvador, BA, Brazil.

Correspondence to: Ricardo Riccio Oliveira, Rua Waldemar Falcão 121 Candeal, 40296-710 Salvador, Bahia, Brasil. Tel.: +55 71 3176 2347 . E-mail: ricardo.riccio@ bahia.fiocruz.br 


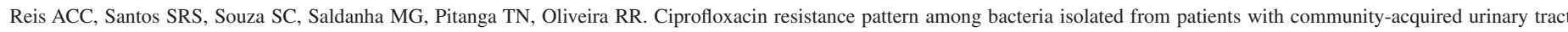
infection. Rev Inst Med Trop Sao Paulo. 2016;58:53.

Regarding fluoroquinolones, its resistance depends essentially on three factors: the ability to select resistant mutants; the ability to reach concentrations that are able to avoid the resistance selection; and the ability to act against mutant bacteria generated during previous treatments with other fluoroquinolones ${ }^{15,16}$.

Due to an increasing therapeutic failure observed in empirical treatment, it has become important to identify the pattern of susceptibility and resistance of bacterial agents, through in vitro antimicrobial susceptibility testing, which can guide the therapeutic approach ${ }^{17}$. Because of the growing resistance observed to ciprofloxacin and to its indiscriminate use, it is important to understand the profile of resistance to this drug in our population, so as to minimize the consequences to the population. The aim of this study was to identify the main bacterial species associated with community-acquired UTI and to assess the pattern of ciprofloxacin susceptibility among bacteria isolated from urine cultures of outpatients seen in the Santa Helena Laboratory, in Camaçari, Bahia, Brazil.

\section{MATERIAL AND METHODS}

This is a retrospective study conducted in all the patients with community-acquired UTI seen in Santa Helena Laboratory, Camaçari, Bahia, Brazil during five years, from 2010 to 2014. All urine samples received at the laboratory are routinely subjected to culture in blood agar plates (BAP) and MacConkey agar (MAC) culture media by a 0.01 calibrated platinum loop. Bacterial colony counting was performed 24 hours after incubation at $37^{\circ} \mathrm{C}$. A Gram stain was performed when bacterial growth was observed only in BAP, whereas when bacterial growth was observed in both culture media, the identification of bacterial species and the antibiogram were performed by using the MicroScan WalkAway plus System (Siemens Healthcare, Puteaux, France).

The MicroScan system consists of plates impregnated with substances used in the biochemical identification of bacterial species, as well as antimicrobial agents in its respective dilution for the antimicrobial susceptibility test.

The laboratory database, managed by the Smart Lab software (Pixeon, Florianóplis, SC, Brazil), was queried in order to extract all the individuals who had urine culture results with more than 100,000 colony-forming units per milliliter $(\mathrm{CFU} / \mathrm{mL})$, considered as positive cultures. Moreover, since a large proportion of patients seen in clinical laboratories initiate empirical antimicrobial therapy before they undergo the microbiological examination of urine, we also included in this study patients with urine culture results between 50,000 and 100,000 CFU/mL. Another inclusion criterion was to have performed the susceptibility test for ciprofloxacin in the isolated bacteria.

A total of 1,710 positive urine cultures examined between 2010 and 2014 were initially selected. Sixty-nine isolates were excluded due to the following reasons: 1 isolate because of a possible contamination; 1 isolate due to the lack of antibiogram result; 3 isolates had no CFU/mL information; 9 isolates had no further microbiological identification; 26 positive cultures were not from urine samples; and 29 isolates did not have the susceptibility test for ciprofloxacin. Therefore, 1,641 results that met the inclusion criteria were enrolled in this study for further analysis.
The following information was collected from each participant in this study: a) registration number; b) sample collection date; c) gender; d) age; e) bacterial species isolated in the urine culture; and f) susceptibility test results for ciprofloxacin and other antibiotics.

Collected data were analyzed by the SPSS (IBM Software, New York, N.Y., USA) and GraphPad Prism (GraphPad Software, San Diego, California, USA) software. The frequency of susceptibility to each of the tested antibiotics over the five years of the study and also the frequency of each etiological agent isolated were presented as percentage. The chisquare test was used to compare proportions between two groups. Results were considered statistically significant when the $p$-value was $<0.05$.

\section{Ethical considerations}

This protocol was submitted and approved by the Research Ethics Committee of the Gonçalo Moniz Research Center, FIOCRUZ-BA (CAAE: 42943715.5.0000.0040). This study fulfilled the ethical criteria established by the resolution 466/2012 of the Brazilian National Council of Health and was developed in accordance with the Declaration of Helsinki of 1964 as amended in 2013.

\section{RESULTS}

Most of the 1,641 evaluated individuals were females $(1,396 ; 85.1 \%)$ and the median age was 33 years, ranging from zero to 95 years old. The most frequent age was 30 years, representing $4.1 \%$ of the total. About $45 \%$ of subjects included in this study were from Camaçari, a municipality located approximately $50 \mathrm{~km}$ away from Salvador, the capital of the Bahia State. The remaining individuals were from other neighboring municipalities, with around 11\% coming from Salvador, the State capital, and more than $99 \%$ of the total evaluated individuals coming from the Metropolitan Region of Salvador, a geographic region involving 13 neighboring municipalities of the capital.

Fourteen bacterial genera were identified in the urine samples analyzed during the period of the study, as follows: Acinetobacter, Citrobacter, Enterobacter, Enterococcus, Hafnia, Morganella, Pantoea, Proteus, Providencia, Pseudomonas, Serratia, Escherichia, Klebsiella and Staphylococcus. The most frequently isolated species were Escherichia coli (66.4\%), followed by Klebsiella pneumoniae $(9.6 \%)$ and Staphylococcus saprophyticus (1.5\%). Other species accounted for $22.5 \%$ of all the positive urine cultures (Fig. 1).

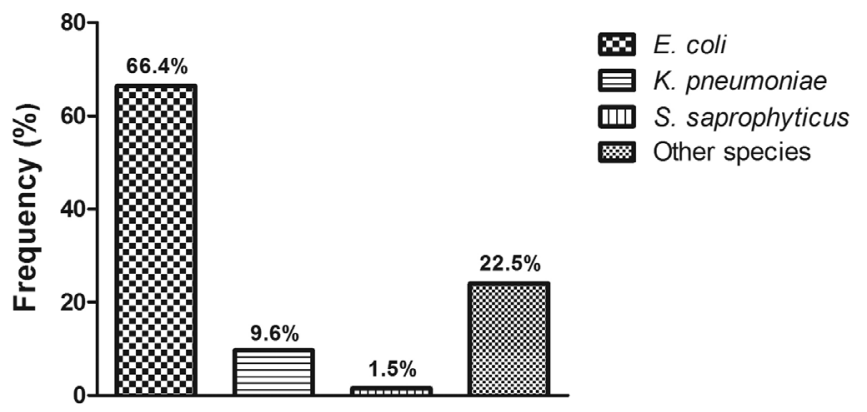

Fig. 1 - Frequency of the bacterial species isolated from urine samples of individuals with urinary tract infection evaluated from 2010 to $2014(\mathrm{n}=1,641)$. 


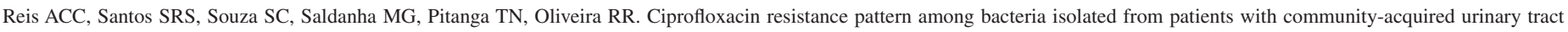
infection. Rev Inst Med Trop Sao Paulo. 2016;58:53.

All the bacterial species isolated from urine samples of patients included in this study were evaluated regarding the susceptibility for 44 different antibiotics. However, only seven of the antimicrobial agents were tested in more than $80 \%$ of the samples, which were considered for further analysis (Fig. 2). Resistance to ampicillin was observed in 55.9\% of the isolated species, sulfamethoxazole+trimethoprim showed $33.6 \%$ of bacterial resistance, ciprofloxacin $18.4 \%$, levofloxacin $18.0 \%$, gentamicin $6.3 \%$, cefepime $3.7 \%$ and amikacin showed the lower frequency $(1.3 \%)$ of bacterial resistance (Fig. 2).

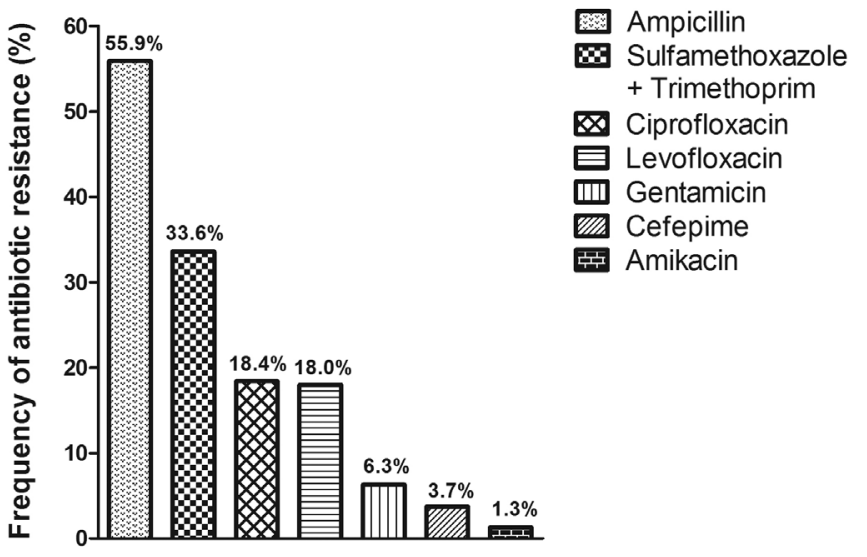

Fig. 2 - Frequency of bacterial resistance for seven antibiotic tested in more than $80 \%$ of all the positive urine samples of individuals with urinary tract infection evaluated from 2010 to $2014(\mathrm{n}=1,513)$.

An increased bacterial resistance to ciprofloxacin has been shown (18.4\% of ciprofloxacin resistant bacteria), and this resistance was more frequent in UTI of men (32.7\%) than of women (15.9\%; $p<0.001$; Fig. 3).

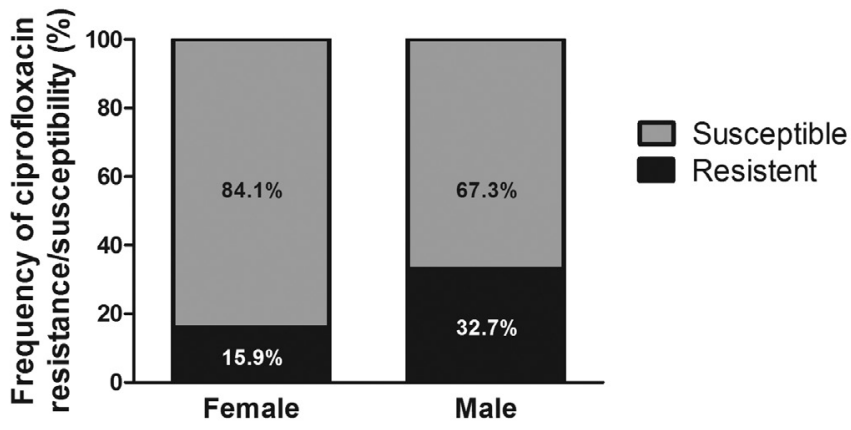

Fig. 3 - Frequency of ciprofloxacin resistance and susceptible bacteria isolated from urine samples of males and females individuals with urinary tract infection $(p<0.001 ; \mathrm{n}=1,641)$

Regarding the bacterial species resistant to ciprofloxacin, we observed a higher frequency of ciprofloxacin resistant E. coli $(22.4 \%)$, when compared to K. pneumoniae $(14.6 \%)$ or to the frequency of ciprofloxacin resistance observed in other species $(8.9 \% ; p<0.05$; Fig. 4). Moreover, we did not find a significant ciprofloxacin resistance in $S$. saprophyticus isolated from urine samples in this study.

Figure 5 shows the progress of ciprofloxacin resistance for each bacterial species isolated from urine samples of individuals with UTI

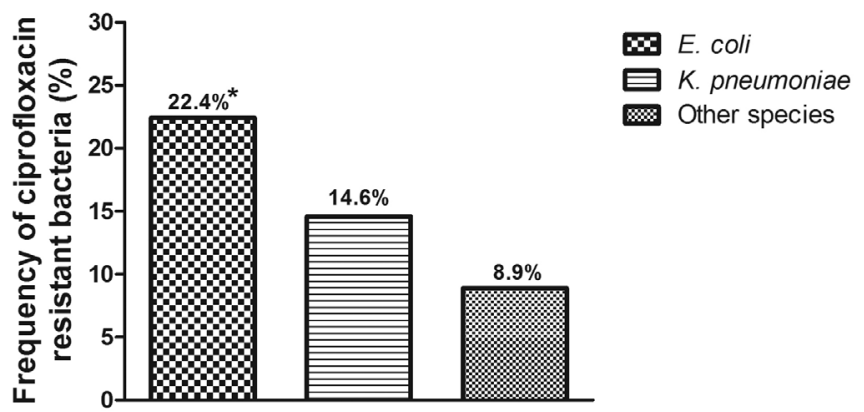

Fig. 4 - Frequency of ciprofloxacin resistance of bacteria isolated from urine samples of individuals with urinary tract infection evaluated from 2010 to 2014 ( $\mathrm{n}=1,641 ; * p<0.05)$.

during the study (2010 to 2014). The overall ciprofloxacin resistance, regardless of the bacterial species, remained constant over time, ranging from $14 \%$ in 2010 to $17 \%$ in 2014 ( $p$ non-significant). When analyzing each bacterial species alone, we observed that both $K$. pneumoniae and $S$. saprophyticus kept a low and constant frequency of resistance to ciprofloxacin $(<10.0 \%)$ over the years, below the overall ciprofloxacin resistance rate. However, E. coli has shown the highest ciprofloxacin resistance rate, which has increased over the years, ranging from $16 \%$ in 2010 to $36 \%$ in $2014(p<0.001)$. Other bacterial species have shown a high resistance rate in $2010(33.0 \%)$, which has been significantly reduced to $17 \%$ in $2014(p<0.01)$.

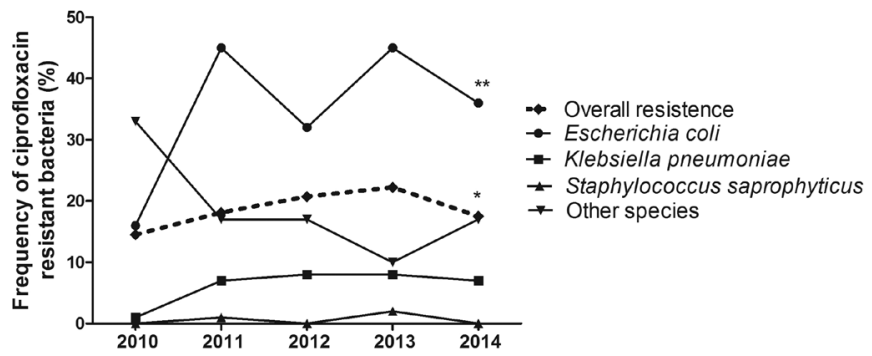

Fig. 5 - Frequency of ciprofloxacin resistance of bacteria isolated from urine samples of individuals with urinary tract infection evaluated from 2010 to $2014(\mathrm{n}=1,641)$. *comparison of the rate of ciprofloxacin resistance for "other bacterial species", between 2010 and 2014 $(p<0.01)$; **comparison of the rate of ciprofloxacin resistance for Escherichia coli between 2010 and $2014(p<0.01)$

\section{DISCUSSION}

Due to the indiscriminate and inconsequent use of antibiotics, followed by an increase in the bacterial resistance rates, this study aimed to evaluate the pattern of antimicrobial susceptibility of bacteria isolated from patients with community-acquired UTI seen at the Laboratório Santa Helena in Camaçari, Bahia, Brazil. Moreover, we identified the major bacterial species associated with UTI and described the profile of resistance to ciprofloxacin.

UTIs are more frequent in female patients and it has been shown that most of UTIs are caused by microorganisms from the intestinal microbiota. This may explain the highest frequency of UTIs observed in women when compared to men, which is often attributed to a shorter 


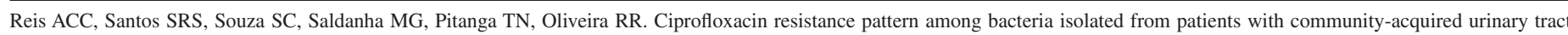
infection. Rev Inst Med Trop Sao Paulo. 2016;58:53.

urethra that facilitates colonization by these microorganisms ${ }^{18,19}$. Furthermore, another mechanism that could explain the lower frequency of UTI in men would be the prostatic fluid, which has antibacterial substances ${ }^{20}$.

The most frequent microorganisms in UTIs are gram-negative bacilli, accounting for $90 \%$ of the reported cases, whereas gram-positive cocci are responsible for only $6 \%$ of all UTIs ${ }^{21}$. Several studies have shown that Escherichia coli is the major bacterial species associated with UTIs, and Klebsiella pneumoniae is the second most important bacteria in this type of infection ${ }^{17,21-24}$. Among the gram-positive cocci, studies conducted with Brazilian patients have demonstrated that Staphylococcus saprophyticus is the most common, corroborating our findings ${ }^{25}$. S. saprophyticus is a coagulase-negative staphylococcus that has the ability to adhere to the urogenital epithelium, being sexual intercourse a possible infection route for this bacterial species ${ }^{26}$.

The early introduction of effective drugs against bacterial infections in the last century has changed the medical behavior and has significantly reduced the mortality rates due to these agents. However, the widespread use of antibiotics has induced different mechanisms of bacteria resistance to these drugs ${ }^{27}$. Bacterial resistance is naturally developed, being a consequence of bacteria adaptation to the environment. The exposure of microorganisms to different antibiotics increases the selective pressure and favors the development of resistance ${ }^{28}$. The most frequently prescribed antibiotics to treat UTIs are sulfamethoxazole+trimethoprim, fluoroquinolones (ciprofloxacin or norfloxacin), $1^{\text {st }}$ and $2^{\text {nd }}$ generations of cephalosporins, amoxicillin + clavulanate and nitrofurantoin ${ }^{29}$. The knowledge on the regional pattern of bacterial resistance is critical to guide the medical staff to choose an appropriate antibiotic for the treatment of UTI patients ${ }^{30}$.

In this study, we have shown that bacteria isolated from UTIs patients have a high rate of resistance to ampicillin, sulfamethoxazole+trimethoprim and ciprofloxacin. This may be explained by the fact that more than $60 \%$ of isolated bacteria were Enterobacteriaceae, which, in general and with few exceptions, such as E. coli, exhibit intrinsic resistance to ampicillin ${ }^{31}$. The association Sulfamethoxazole+trimethoprim is considered the firstline drug to treat acute cystitis, being the first antibiotic to be tested in clinical trials conducted in the early 30 's. Ciprofloxacin, in turn, is widely used due to its excellent activity against gram-negative bacteria, but the abuse of this antibiotic including its prophylactic use, has induced a progressive increase in antimicrobial resistance rates ${ }^{32}$. Bacterial resistance to sulfamethoxazole+trimethoprim and ciprofloxacin associated with UTIs is reaching critical levels in many parts of the world ${ }^{33,34}$.

We have shown that resistance to ciprofloxacin was more frequent in males, although most of the participants included in this study were female. Lately, more men than women are affected by severe and chronic health conditions, and a higher mortality rate caused by the most frequent causes of death has been observed. Despite the higher morbidity and mortality rates observed in men, they attend health care services less frequently than women. Moreover, other issues to be considered in men's health behavior are self-medication and/ or a greater likelihood of men not to follow correctly the treatment, which, otherwise, contribute to increase the bacterial resistance rates ${ }^{35-39}$.

Etiological agents of UTIs can variety widely depending on the geographical region analyzed. Therefore, it is important to monitor the antimicrobial susceptibility profile so that we can look for further therapeutic options that are specific for each region ${ }^{40}$. Considering that $E$. coli and $K$. pneumoniae are often isolated from urine samples of patients with UTI, the increased antimicrobial resistance observed for these species has drawn attention worldwide. Moreover, quinolones, especially ciprofloxacin, are frequently used in the prophylaxis and treatment of UTIs. The prophylactic use of quinolones has a significant role in the increasing emergence of bacteria resistant to these antimicrobials. In Brazil, a high incidence of bacteria resistant to quinolones has been associated with UTI. In this study, a high rate $(36 \%)$ of ciprofloxacin resistant $E$. coli strains have been shown, representing almost twice the rate observed in other studies in Brazil and other countries, ranging from 20 to $25 \%$ of resistance ${ }^{23,24}$.

Bacteria associated with UTIs have shown a significant reduction in the susceptibility to antimicrobials normally prescribed to treat these patients. This phenomenon has been observed in several countries, which progressively encourages the testing of antibiotic susceptibility in all bacteria isolated from urine cultures ${ }^{1,41,42}$. The increase in bacterial resistance rates may be due to the empirically medical prescription, individual self-medication or a low adherence to treatment, inefficient hospital infection control services and poor hygiene. Ciprofloxacinresistant bacterial infections have been mainly associated with chromosomal mutations that alters DNA gyrase and topoisomerase IV, upregulation of the expression of native efflux pumps, alteration of the amount or porins types and transference of resistance genes by plasmids ${ }^{43,44}$. In this study, we were not able to detect the specific resistance mechanisms but, instead, we observed no inhibition of bacterial growth by the tested antibiotic concentration.

It is important to point out that the minimum susceptibility rate that supports empirical treatment of UTI is $80 \%$ of all the strains of a specific bacterium in a given region ${ }^{45}$. Considering that in this study we found an overall ciprofloxacin resistance rate of nearly $20 \%$, in addition to the high rates of $E$. coli resistance to ciprofloxacin, a greater concern about the empirical use of ciprofloxacin is required. Our data points out the urgent need for awareness of antibiotics use and prescription, especially in infections caused by E. coli. Supporting this statement, since 2008 it has been observed a global spread, including in Brazil, of a new specific clone of $E$. coli, the sequence type 131 (ST131) $)^{46-48}$. Currently, this is one of the most frequent pathogenic $E$. coli lineage associated with extraintestinal infections, and almost all of the ST131 clones are resistant to fluoroquinolones ${ }^{49-51}$, which could, at least in part, explain our findings.

In this study, we have shown a slight decrease in the frequency of resistance to ciprofloxacin in the year 2014. This may be attributed to a policy of the rational use of antimicrobials, which has started in 2011 in Brazil. This policy limited the sale of antimicrobial agents and, from then on, the sale of antibiotics by drugstores requires a medical prescription ${ }^{52}$.

Bacterial resistance has become a public health issue and has increasingly been associated with risk factors that put life in danger. Awareness is needed of both the population and health professionals about the importance for the correct use of antibiotics, and it is mandatory to take into account the result of antibiotics susceptibility tests. The ciprofloxacin use should be performed only after the microbial susceptibility confirmation, and it is necessary to find other alternatives 


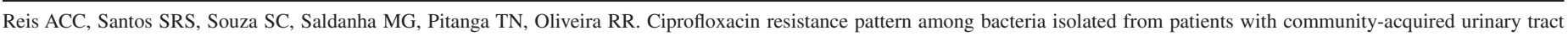
infection. Rev Inst Med Trop Sao Paulo. 2016;58:53.

for the empirical treatment. The bacterial resistance prevention can be performed through control measures that limit the spread of resistant bacteria and the rational use of antimicrobial policy.

\section{ACKNOWLEDGEMENTS}

We greatly appreciate the cooperation of the Laboratório Santa Helena team.

\section{CONFLICT OF INTEREST}

None of the authors declares any conflict of interest.

\section{AUTHOR CONTRIBUTIONS}

ACCR and RRO: conceived the study design. ACCR and SRSS: collected all the data. ACCR, SRSS and RRO: analyzed all the data. SCS, MGS, TNP and RRO: performed the discussion of the study design and all the results. ACCR, SRSS, TNP and RRO: wrote the paper. All the authors read and approved the final manuscript.

\section{REFERENCES}

1. Camargo CB, Pedro CC, Lourenço DS, Gironi RH, Martinez R. Infecção de vias urinárias na comunidade de Ribeirão Preto, SP: etiologia, sensibilidade bacteriana a antimicrobianos e implicações terapêuticas. Med Ribeirão Preto. 2002;35:173-8.

2. Mazili PM, Carvalho Junior AP, Almeida FG. Infecção do trato urinário. Rev Bras Med. 2011;68:74-81.

3. Oliveira FA, Nogueira KS. Resistência à fluoroquinolonas em Escherichia coli isoladas em cultura de urina. Rev Bras Anal Clin. 2011;43:152-4

4. Lorente Garín JA, Placer Santos J, Salvadó Costa M, Segura Alvarez C, Gelabert-Mas A. Evolución de la resistencia antibiótica en las infecciones urinarias adquiridas en la comunidad. Rev Clin Esp. 2005;205:259-64.

5. Dromigny JA, Nabeth P, Juergens-Behr A, Perrier-Gros-Claude JD. Risk factors for antibiotic-resistant Escherichia coli isolated from community-acquired urinary tract infections in Dakar, Senegal. J Antimicrob Chemother. 2005;56:236-9.

6. Labreche MJ, Frei CR. Declining susceptibilities of gram-negative bacteria to the fluoroquinolones: effects on pharmacokinetics, pharmacodynamics, and clinical outcomes. Am J Health Syst Pharm. 2012;69:1863-70.

7. Marques ML, Chade DC, Dourado FL. Aumento da resistência bacteriana no controle de infecção urinária adquirida na comunidade. Sinop Urol. 2005;9:121-2.

8. Andriole VT. The quinolones: past, present, and future. Clin Infect Dis. 2005;41 Suppl 2:S113-9.

9. Bartoloni A, Pallecchi L, Riccobono E, Mantella A, Magnelli D, Di Maggio T, et al Relentless increase of resistance to fluoroquinolones and expanded-spectrum cephalosporins in Escherichia coli: 20 years of surveillance in resource-limited settings from Latin America. Clin Microbiol Infect. 2013;19:356-61.

10. Santana TC, Pereira EM, Monteiro SG, Carmo MS, Turri RJ, Figueiredo PM. Prevalência e resistência bacteriana aos agentes antimirobianos de primeira escolha nas infecções do trato urinário no município de São Luís-MA. Rev Patol Trop. 2012;41:409-18.

11. D’Addazio LB, Moraes SR. Microrganismos isolados de infecção do trato urinário da comunidade. Rev Saúde. 2015;6:11-3

12. Wright GD. Bacterial resistance to antibiotics: enzymatic degradation and modification. Adv Drug Deliv Rev. 2005;57:1451-70.
13. Grail BM, Payne JW. Conformational analysis of bacterial cell wall peptides indicates how particular conformations have influenced the evolution of penicillin-binding proteins, beta-lactam antibiotics and antibiotic resistance mechanisms. J Mol Recognit. 2002;15:113-25.

14. Machuca J, Briales A, Diaz-de-Alba P, Martínez-Martínez L, Pascual A, RodríguezMartínez JM. Effect of the efflux pump QepA2 combined with chromosomally mediated mechanisms on quinolone resistance and bacterial fitness in Escherichia coli. J Antimicrob Chemother. 2015;70:2524-7.

15. Horna Quintana G, Silva Diaz M, Vicente Taboada W, Tamariz Ortiz JH. Concentración mínima inhibitoria y concentración mínima bactericida de ciprofloxacina en bacterias uropatógenas aisladas en el Instituto Nacional de Enfermedades Neoplásicas. Rev Med Hered. 2005;16:39-45.

16. Han JH, Nachamkin I, Tolomeo P, Mao X, Bilker WB, Lautenbach E. Temporal changes in resistance mechanisms in colonizing Escherichia coli isolates with reduced susceptibility to fluoroquinolones. Diagn Microbiol Infect Dis. 2013;76:491-6.

17. Pires MC, Frota KS, Martins Junior PO, Correia AF, Cortez-Escalante JJ, Silveira CA. Prevalência e suscetibilidades bacterianas das infecções comunitárias do trato urinário, em Hospital Universitário de Brasília, no período de 2001 a 2005. Rev Soc Bras Med Trop. 2007;40:643-7.

18. Mazzulli T. Antimicrobial resistance trends in common urinary pathogens. Can J Urol 2001;8 Suppl 1:2-5

19. Blatt JM, Miranda MC. Perfil dos microrganismos causadores de infecções do trato urinário em pacientes internados. Rev Panam Infectol. 2005;7:10-4.

20. Soares LA, Nishi CY, Wagner HL. Isolamento das bactérias causadoras de infecções urinárias e seu perfil de resistência aos antimicrobianos. Rev Bras Med Fam Com. 2006;2:84-92.

21. Costa LC, Belém LF, Silva PM, Pereira HS, Silva EDJ, Leite TR, et al. Infecções urinárias em pacientes ambulatoriais: prevalência e perfil de resistência aos antimicrobianos. Rev Bras Anal Clin. 2010;42:175-80.

22. Silveira SA, Araújo MC, Fonseca FM, Okura MH, Oliveira AC. Prevalência e suscetibilidade bacteriana em infecções do trato urinário de pacientes atendidos no Hospital Universitário de Uberaba. Rev Bras Anal Clin. 2010;42:157-60.

23. Vieira JM, Saraiva RM, Mendonça LC, Fernandes VO, Pinto MR, Vieira AB Suscetibilidade antimicrobiana de bactérias isoladas de infecções do trato urinário de pacientes atendidos no Hospital Universitário Bettina Ferro de Souza, Belém - PA. Rev Bras Anal Clin. 2007;39:119-21.

24. Horner R, Vissotto R, Mastella A, Salla A, Meneghetti B, Dal Forno NL, et al. Prevalência de microrganismos em infecções do trato urinário de pacientes atendidos no Hospital Universitário de Santa Maria. Rev Bras Anal Clin. 2006;38:147-50.

25. Braoios A, Turatti TF, Meredija LC, Campos TR, Denadai FH. Infecções do trato urinário em pacientes não hospitalizados: etiologia e padrão de resistência aos antimicrobianos. J Bras Patol Med Lab. 2009;45:449-56.

26. Gillespie WA, Sellin MA, Gill P, Stephens M, Tuckwell LA, Hilton AL. Urinary tract infection in young women, with special reference to Staphylococcus saprophyticus. J Clin Pathol. 1978;31:348-50.

27. Silveira GP, Nome F, Gesser JC, Sá MM, Terenzi H. Estratégias utilizadas no combate a resistência bacteriana. Quím Nova. 2006;29:844-55.

28. Santos NQ. A resistência bacteriana no contexto da infecção hospitalar. Texto Contexto Enferm. 2004;13:64-70

29. Heilberg IP, Schor N. Abordagem diagnóstica e terapêutica na infecção do trato urinário - ITU. Rev Assoc Med Bras. 2003;49:109-16. 
Reis ACC, Santos SRS, Souza SC, Saldanha MG, Pitanga TN, Oliveira RR. Ciprofloxacin resistance pattern among bacteria isolated from patients with community-acquired urinary tract infection. Rev Inst Med Trop Sao Paulo. 2016;58:53.

30. Koch CR, Ribeiro JC, Schnor OH, Zimmermann BS, Muller FM, J DA, et al. Resistência antimicrobiana dos uropatógenos em pacientes ambulatoriais, 2000-2004. Rev Soc Bras Med Trop. 2008;41:277-81.

31. Clinical and Laboratory Standards Institute. Performance standards for antimicrobial susceptibility testing: twenty-second informational supplement. Wayne: CLSI; 2012.

32. Magalhães V, Farias RB, Agra G, Lima AL. Etiologia e perfil de resistência das bactérias isoladas a partir de uroculturas oriundas de mulheres acima dos 18 anos. Rev Bras Med. 2009;66 Supl 2:11-6.

33. Drekonja DM, Johnson JR. Urinary tract infections. Prim Care. 2008;35:345-67.

34. Arslan H, Azap OK, Ergönül O, Timurkaynak F. Risk factors for ciprofloxacin resistance among Escherichia coli strains isolated from community-acquired urinary tract infections in Turkey. J Antimicrob Chemother. 2005;56:914-8.

35. Courtenay WH. Constructions of masculinity and their influence on men's well-being: a theory of gender and health. Soc Sci Med. 2000;50:1385-401.

36. Laurenti R, Jorge MH, Gotlieb SL. Perfil epidemiológico da morbi-mortalidade masculina. Ciênc Saúde Coletiva. 2005;10:35-46.

37. Luck M, Bamford M, Williamson P. Men's health: perspectives, diversity and paradox. Oxford: Blackwell Science; 2000.

38. Figueiredo W. Assistência à saúde dos homens: um desafio para os serviços de atenção primária. Ciênc Saúde Coletiva. 2005;10:105-9.

39. Pinheiro RS, Viacava F, Travassos C, Brito AS. Gênero, morbidade, acesso e utilização de serviços de saúde no Brasil. Ciênc Saúde Coletiva. 2002;7:687-707.

40. Gordon KA, Jones RN. Susceptibility patterns of orally administered antimicrobials among urinary tract infection pathogens from hospitalized patients in North America: comparison report to Europe and Latin America. Results from the SENTRY Antimicrobial Surveillance Program (2000). Diagn Microbiol Infect Dis. 2003;45:295-301

41. Mishra MP, Sarangi R, Padhy RN. Prevalence of multidrug resistant uropathogenic bacteria in pediatric patients of a tertiary care hospital in eastern India. J Infect Public Health. In Press 2015.

42. Fasugba O, Gardner A, Mitchell BG, Mnatzaganian G. Ciprofloxacin resistance in community- and hospital-acquired Escherichia coli urinary tract infections: a systematic review and meta-analysis of observational studies. BMC Infect Dis. 2015;15:545.
43. Jacoby GA. Mechanisms of resistance to quinolones. Clin Infect Dis. 2005;41 Suppl 2:S120-6.

44. Kim ES, Hooper DC. Clinical importance and epidemiology of quinolone resistance. Infect Chemother. 2014;46:226-38.

45. Martins F, Vitorino J, Abreu A. Avaliação do perfil de susceptibilidade aos antimicrobianos de microrganismos isolados em urinas na região do Vale do Sousa e Tâmega. Acta Med Port. 2010;23:641-6.

46. Peirano G, Asensi MD, Pitondo-Silva A, Pitout JD. Molecular characteristics of extendedspectrum beta-lactamase-producing Escherichia coli from Rio de Janeiro, Brazil. Clin Microbiol Infect. 2011;17:1039-43.

47. Nicolas-Chanoine MH, Blanco J, Leflon-Guibout V, Demarty R, Alonso MP, Caniça MM et al. Intercontinental emergence of Escherichia coli clone O25:H4-ST131 producing CTX-M-15. J Antimicrob Chemother. 2008;61:273-81.

48. Johnson JR, Johnston B, Clabots C, Kuskowski MA, Castanheira M. Escherichia coli sequence type ST131 as the major cause of serious multidrug-resistant E. coli infections in the United States. Clin Infect Dis. 2010;51:286-94.

49. Banerjee R, Johnston B, Lohse C, Chattopadhyay S, Tchesnokova V, Sokurenko EV, et al The clonal distribution and diversity of extraintestinal Escherichia coli isolates vary according to patient characteristics. Antimicrob Agents Chemother. 2013;57:5912-7.

50. Matsumura Y, Yamamoto M, Nagao M, Ito Y, Takakura S, Ichiyama S. Association of fluoroquinolone resistance, virulence genes, and IncF plasmids with extendedspectrum-beta-lactamase-producing Escherichia coli sequence type 131 (ST131) and ST405 clonal groups. Antimicrob Agents Chemother. 2013;57:4736-42.

51. Johnson JR, Johnston B, Kuskowski MA, Sokurenko EV, Tchesnokova V. Intensity and mechanisms of fluoroquinolone resistance within the H30 and H30Rx subclones of Escherichia coli sequence type 131 compared with other fluoroquinolone-resistant E. coli. Antimicrob Agents Chemother. 2015;59:4471-80.

52. Brasil. Agência Nacional de Vigilância Sanitária. Resolução-RDC nº 20, de 5 de maio de 2011 [cited $2016 \mathrm{Feb} 25$ ]. Available from: http://www.anvisa.gov.br/sngpc/ Documentos2012/RDC\%2020\%202011.pdf?jornal=\%E2\%80\%A6

Received: 23 December 2015

Accepted: 25 February 2016 